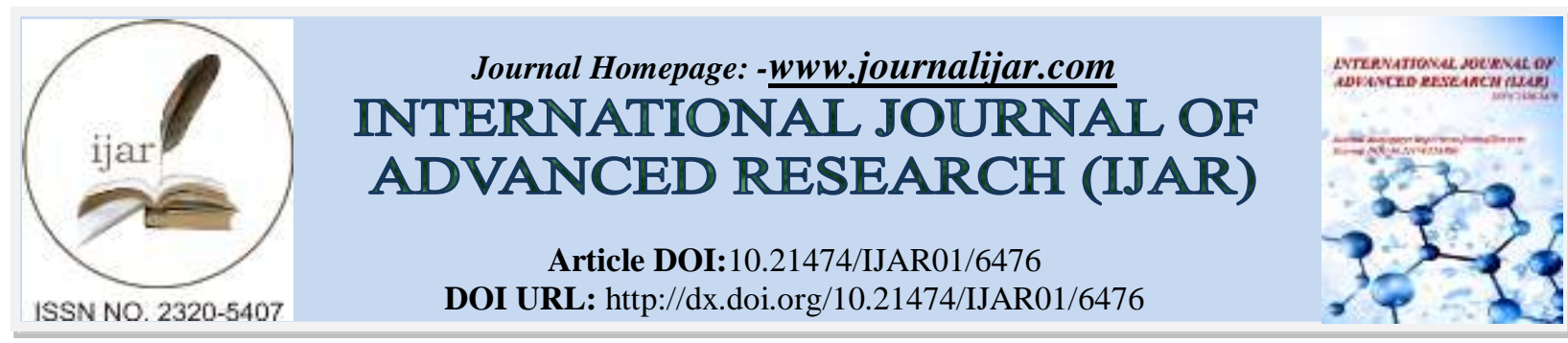

RESEARCH ARTICLE

\title{
ANTIBIOSIS EFFECT OF PHLOROGLUCINOL ON THE LARVAE OF HERBIVOROUS INSECT BACTROCERA CUCURBITAE (COQUILLETT) (DIPTERA: TEPHRITIDAE).
}

\author{
Shivali Puri and Satwinder Kaur Sohal. \\ Department of Zoology, Guru Nanak Dev University, Amritsar, India (143001).
}

\section{Manuscript Info}

Manuscript History

Received: 13 December 2017

Final Accepted: 15 January 2018

Published: February 2018

Keywords:-

Phloroglucinol, Bactrocera cucurbitae, Pest.

\section{Abstract}

The secondary metabolite, phloroglucinol is a simple phenolic compound, widely distributed in plants. In the present study, the influence of phloroglucinol was investigated on the larvae of Bactrocera cucurbitae (Coquillett) (Diptera: Tephritidae) which is a major pest of plants from cucurbitacae family. Control and five concentrations $(5,25,125,625$ and $3125 \mathrm{ppm})$ of phloroglucinol incorporated in artificial diet were fed to first, second and third instar larvae and parameters like larval period, total developmental period, percent pupation, percent emergence, larval weight , pupal weight, mean relative growth rate and food assimilated were studied. The larval growth of first and second instar was affected in a negative manner while the third instar larval growth was not affected by phloroglucinol. Percent pupation and percent emergence decreased significantly in a dose dependent manner in first and second instar larvae. The present findings indicate immense potential of phloroglucinol to control the insect pest.

Copy Right, IJAR, 2018,. All rights reserved.

\section{Introduction:-}

The degradation of environment and deteriorating public health caused by excessive and persistent use of pesticides has been highlighted in a number of studies. Suitable alternatives that have low environmental impact and are safe to humans need to be found so that reliance on pesticides for pest control can be reduced. This requires a consistent effort by entomologists to find and develop ecofriendly and biodegradable compounds for the management of insect pests. Insects and plants have been living together for more than 350 million years (War et al., 2012). A lot of progress has been made in understanding insect plant interactions. These studies have unravelled a wide range of plant secondary metabolites which provide a chemical barrier to phytophagous insects and other herbivores. Exploration of these secondary compounds with an intention to exploit them for regulating pest population has recently become a subject of intense research. These compounds of plant origin are harmless to non target organisms and are readily biodegradable, so can be a promising alternative to organic pesticides. Moreover, the use of natural plant compounds as insecticides has numerous advantages compared to synthetic materials. Also, the advent of advanced molecular techniques has made it possible to breed crop varieties with higher content which can enhance commercial value while affording resistance.

Among the secondary metabolites, plant phenols play a pivotal role in host plant resistance against pests. They reduce damage caused by insects through their deterrent or antifeedent effect (Simmonds et al., 1990). They negatively influence the development of pests by curbing the products of digestive enzymes, causing potential anti- 
digestive effect, causing midgut lesions by producing oxygen free radicals and deterrence of feeding (Ghosh et al .,2002; Mann and Kufermann, 2012).

Phloroglucinol is the simplest member of the phloroglucinol family of organic compounds consisting of more than 100 naturally occurring derivatives that exhibit a wide array of useful biological activities (Singh et al., 2009). Phloroglucinol and its derivatives have been used in pharmaceuticals, the dyeing industry and plant tissue culture (Singh and Bharat, 2006; Singh et al., 2010). In medicine, phloroglucinols have various useful biological properties such as antiinflammatory, anti-cancer, anti- microbial, antioxidant and neuro regenerative activities (Pulido et al., 2000; Jafri et al., 2006; Kang et al., 2006; Singh et al., 2009; Xu et al., 2013; Ryu et al., 2013). However it has not been much explored for its anti insect potential. The present study therefore aimed at investigating the influence of phloroglucinol on the development of melon fruit fly $B$. cucurbitae, a pest of significant agricultural importance. Though native to India, its potential for rapid range expansion owing to its great mobility, high fecundity, fertility, life span and a short egg eclosion period (Kumar et al., 2001) has resulted in its spread throughout the tropical and subtropical regions. Crop losses resulting from its infestation often reach proportions greater than $60 \%$ (Kapoor, 2000).

\section{Materials and Methods:-}

The larvae of $B$. cucurbitae were procured from vegetables grown in kitchen gardens of Guru Nanak Dev University campus. The flies emerged from the larvae were identified according to the taxonomic keys given by Kapoor (1993) and White and Elson-Harris (1992). The flies were reared in wire mesh cages $(45 \times 45 \times 50 \mathrm{~cm})$ in the insect culture room according to the methodology given by Gupta et al. (1978). The insect culture was maintained at a temperature of $25 \pm 2{ }^{\circ} \mathrm{C}$, relative humidity $70-80 \%$ and photoperiod of $10 \mathrm{~h}$ light: $14 \mathrm{~h}$ dark. The flies were provided food comprising of protinex mixed with a pinch of vitamin $\mathrm{E}$ and sugar solution. Pumpkin pieces were placed in wire mesh cages for oviposition.

Test chemical:-

Phloroglucinol, a simple phenol was purchased from Loba Chemie Private Limited, Mumbai, India.

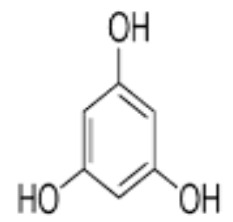

\section{Bioassays:-}

Experiments were conducted on the first, second and third instar larvae. The larvae of same age were obtained by releasing around 150 pairs of gravid flies in rescholar's wire mesh cages provided with fresh pumpkin pieces for oviposition. After an interval of $8 \mathrm{~h}$, the egg laden pumpkin pieces were removed from the cages. The first instar larvae were harvested in saline water after $48 \mathrm{~h}$ of removal of the pumpkin pieces, the second instar larvae were obtained after $72 \mathrm{~h}$ and harvesting of the third instar larvae was done after $96 \mathrm{~h}$. The bioassays were conducted using phloroglucinol concentrations viz. 5, 25, 125, 625, $3125 \mathrm{ppm}$ and water as control. The larvae of different age groups were released in glass vials containing various concentrations of phloroglucinol incorporated in artificial diet. The artificial diet was prepared according to the methodology of Srivastava (1975). The experimental vials were kept in B.O.D. under controlled conditions of temperature, humidity and photoperiod. Each treatment comprised of six replications with 15 larvae in each replication. All experiments were repeated twice. The parameters for studying the antibiosis influence of phloroglucinol included time taken by the larvae to form pupae, number of pupae formed from larvae, time taken for adults to emerge from pupae and percentage emergence. Separate experiments were conducted to study the effect of phloroglucinol on pupal weight of three larval instars. Observations to record the data were made after every $24 \mathrm{~h}$ interval till the termination of experiments.

\section{Nutritional assays:-}

The nutritional assays were done using second instar larvae (64-72h old) of melon fruit fly. The larvae were weighed and placed in glass vials having diet containing various concentrations of phloroglucinol and water as control. The larvae were weighed again after $24 \mathrm{~h}, 48 \mathrm{~h}$ and $72 \mathrm{~h}$ of treatment to assess change in weight of the larvae. The mean relative growth rate (MRGR) was calculated by using the formula of Martinez and Emden (2001) 


$$
\operatorname{MRGR}\left(\frac{\mathrm{mg}}{\mathrm{mg}} / \text { day }\right)=\frac{\log \mathrm{N} \text { final weight }(\mathrm{mg})-\log \mathrm{N} \text { initial weight }(\mathrm{mg})}{\text { time (in days) }}
$$

Food assimilated (FA) was calculated by using the formula given by Khan and Saxena, (1985) after slight modifications.

$$
\mathrm{FA}(\mathrm{mg})=\mathrm{ti} \times \frac{\mathrm{cf}-\mathrm{ci}}{\mathrm{ci}}+\mathrm{tf}-\mathrm{ti}
$$

where $\mathrm{ci}=$ initial weight of control larvae, $\mathrm{cf}=$ final weight of control larvae, $\mathrm{ti}=$ initial weight of treated larvae and $\mathrm{tf}=$ final weight of treated larvae.

\section{Statistical analysis:-}

The data obtained was analysed through one way analysis of variance (ANOVA) and the means of significant parameters were compared by Tukey's honestly difference test using Assistat (7.7).

Table1:-The effect of phloroglucinol on larval period (in days) of B. cucurbitae.

\begin{tabular}{|l|l|l|l|}
\hline $\begin{array}{c}\text { Concentrations } \\
(\mathrm{ppm})\end{array}$ & \multicolumn{1}{c}{$\begin{array}{c}\text { First instar } \\
(\text { Mean } \pm \text { S.E. })\end{array}$} & $\begin{array}{c}\text { Second instar } \\
(\text { Mean } \pm \text { S.E. })\end{array}$ & $\begin{array}{c}\text { Third instar } \\
(\text { Mean } \pm \text { S.E. })\end{array}$ \\
\hline 0 & $9.13 \pm 0.19 \mathrm{a}$ & $7.36 \pm 0.10 \mathrm{~b}$ & $4.35 \pm 0.08$ \\
\hline 5 & $9.04 \pm 0.22 \mathrm{a}$ & $7.46 \pm 0.10 \mathrm{ab}$ & $4.27 \pm 0.07$ \\
\hline 25 & $9.18 \pm 0.16 \mathrm{a}$ & $7.42 \pm 0.08 \mathrm{~b}$ & $4.40 \pm 0.17$ \\
\hline 125 & $9.11 \pm 0.05 \mathrm{a}$ & $7.77 \pm 0.13 \mathrm{ab}$ & $4.36 \pm 0.16$ \\
\hline 625 & $9.53 \pm 0.25 \mathrm{a}$ & $7.63 \pm 0.17 \mathrm{ab}$ & $4.09 \pm 0.12$ \\
\hline 3125 & $9.78 \pm 0.13 \mathrm{a}$ & $7.94 \pm 0.12 \mathrm{a}$ & $4.33 \pm 0.11$ \\
\hline $\mathrm{F}(\mathrm{df}=5)$ & $2.70 *$ & $3.49 *$ & 0.83 n.s. \\
\hline
\end{tabular}

According to the Tukey test $(\mathrm{p}=0.05)$ means having same letter within columns are not significantly different.

$*=$ Significant at $5 \%$ level; n.s. = Non Significant

\begin{tabular}{|c|c|c|c|}
\hline $\begin{array}{l}\text { Concentrations } \\
(\mathrm{ppm})\end{array}$ & $\begin{array}{c}\text { First instar } \\
(\text { Mean } \pm \text { S.E. })\end{array}$ & $\begin{array}{l}\text { Second instar } \\
(\text { Mean } \pm \text { S.E. })\end{array}$ & $\begin{array}{c}\text { Third instar } \\
\text { (Mean } \pm \text { S.E.) }\end{array}$ \\
\hline 0 & $19.92 \pm 0.23 b$ & $15.79 \pm 0.09 a$ & $13.38 \pm 0.04$ \\
\hline 5 & $20.11 \pm 0.10 b$ & $15.85 \pm 0.11 \mathrm{a}$ & $13.36 \pm 0.06$ \\
\hline 25 & $19.96 \pm 0.10 b$ & $15.82 \pm 0.09 \mathrm{a}$ & $13.39 \pm 0.09$ \\
\hline 125 & $20.46 \pm 0.11 b$ & $15.99 \pm 0.09 a$ & $13.42 \pm 0.11$ \\
\hline 625 & $20.29 \pm 0.21 b$ & $16.12 \pm 0.04 a$ & $13.29 \pm 0.15$ \\
\hline 3125 & $21.89 \pm 0.51 \mathrm{a}$ & $16.14 \pm 0.09 a$ & $13.43 \pm 0.10$ \\
\hline $\mathrm{F}(\mathrm{df}=5)$ & $8.53 * *$ & $3.17 *$ & 0.28 n.s. \\
\hline
\end{tabular}

Table2:-The effect of phloroglucinol on total developmental period (in days) of B. cucurbitae.

According to the Tukey test $(\mathrm{p}=0.05)$ means having same letter within columns are not significantly different.

$* *=$ Significant at $1 \%$ level; $*=$ Significant at $5 \%$ level and n.s. $=$ Non Significant

Table3:-The effect of phloroglucinol on percent pupation of B. cucurbitae.

\begin{tabular}{|l|l|l|l|}
\hline $\begin{array}{c}\text { Concentrations } \\
(\mathrm{ppm})\end{array}$ & \multicolumn{1}{c}{$\begin{array}{c}\text { First instar } \\
\text { (Mean } \pm \text { S.E. })\end{array}$} & \multicolumn{1}{c|}{$\begin{array}{c}\text { Second instar } \\
(\text { Mean } \pm \text { S.E. })\end{array}$} & \multicolumn{1}{c|}{$\begin{array}{c}\text { Third instar } \\
(\text { Mean } \pm \text { S.E. })\end{array}$} \\
\hline 0 & $74.44 \pm 3.62 \mathrm{a}$ & $82.22 \pm 2.22 \mathrm{a}$ & $90.00 \pm 1.49$ \\
\hline 5 & $74.44 \pm 4.69 \mathrm{a}$ & $80.00 \pm 2.43 \mathrm{a}$ & $93.33 \pm 1.72$ \\
\hline 25 & $70.00 \pm 3.33 \mathrm{a}$ & $82.22 \pm 2.81 \mathrm{a}$ & $93.33 \pm 2.43$ \\
\hline 125 & $67.78 \pm 2.05 \mathrm{a}$ & $77.78 \pm 3.72 \mathrm{a}$ & $92.22 \pm 2.05$ \\
\hline 625 & $63.33 \pm 2.28 \mathrm{ab}$ & $76.67 \pm 2.85 \mathrm{ab}$ & $94.44 \pm 2.05$ \\
\hline 3125 & $52.22 \pm 2.05 \mathrm{~b}$ & $65.56 \pm 2.68 \mathrm{~b}$ & $92.22 \pm 2.68$ \\
\hline $\mathrm{F}(\mathrm{df}=5)$ & $7.07 * *$ & $4.87 * *$ & $0.52 \mathrm{n}$. .s. \\
\hline
\end{tabular}

According to the Tukey test $(\mathrm{p}=0.05)$ means having same letter within columns are not significantly different. $* *=$ Significant at $1 \%$ level and n.s. = Non Significant. 
Table 4:-The effect of phloroglucinol on larval weight gain $(\mathrm{mg})$ when $64-72 \mathrm{~h}$ old larvae of $B$. cucurbitae were fed on phloroglucinol incorporated in artificial diet.

\begin{tabular}{|c|c|c|c|}
\hline $\begin{array}{l}\text { Concentrations } \\
(\mathrm{ppm})\end{array}$ & $\begin{array}{c}\text { After 24h } \\
(\text { Mean } \pm \text { S.E. })\end{array}$ & $\begin{array}{c}\text { After } 48 \mathrm{~h} \\
(\text { Mean } \pm \text { S.E. })\end{array}$ & $\begin{array}{l}\text { After } 72 \mathrm{~h} \\
(\text { Mean } \pm \text { S.E. })\end{array}$ \\
\hline 0 & $6.303 \pm 0.018 a$ & $9.743 \pm 0.039 a$ & $10.802 \pm 0.052 \mathrm{a}$ \\
\hline 5 & $6.230 \pm 0.022 a$ & $9.553 \pm 0.046 a$ & $10.297 \pm 0.050 \mathrm{~b}$ \\
\hline 25 & $6.098 \pm 0.034 b$ & $8.855 \pm 0.048 b$ & $9.832 \pm 0.063 c$ \\
\hline 125 & $6.060 \pm 0.030 b$ & $8.888 \pm 0.057 b$ & $9.622 \pm 0.072 \mathrm{~cd}$ \\
\hline 625 & $5.992 \pm 0.035 b c$ & $8.728 \pm 0.052 b$ & $9.403 \pm 0.044 d$ \\
\hline 3125 & $5.897 \pm 0.036 c$ & $8.460 \pm 0.079 c$ & $8.928 \pm 0.093 \mathrm{e}$ \\
\hline $\mathrm{F}(\mathrm{df}=5)$ & $24.800 * *$ & $82.988 * *$ & $106.086 * *$ \\
\hline
\end{tabular}

According to the Tukey test $(\mathrm{p}=0.05)$ means having same letter within columns are not significantly different.

$* *=$ Significant at $1 \%$ level

Table5:-The effect of phloroglucinol on pupal weight (mg) of three instars of B. cucurbitae.

\begin{tabular}{|l|l|l|l|}
\hline $\begin{array}{l}\text { Concentrations } \\
(\mathrm{ppm})\end{array}$ & \multicolumn{1}{c}{$\begin{array}{c}\text { First instar } \\
(\text { Mean } \pm \text { S.E. })\end{array}$} & \multicolumn{1}{c|}{$\begin{array}{c}\text { Second instar } \\
(\text { Mean } \pm \text { S.E. })\end{array}$} & \multicolumn{1}{c|}{$\begin{array}{c}\text { Third instar } \\
(\text { Mean } \pm \text { S.E. })\end{array}$} \\
\hline 0 & $11.91 \pm 0.05 \mathrm{ab}$ & $12.94 \pm 0.14 \mathrm{a}$ & $12.162 \pm 0.17$ \\
\hline 5 & $12.12 \pm 0.15 \mathrm{a}$ & $12.88 \pm 0.15 \mathrm{a}$ & $12.150 \pm 0.16$ \\
\hline 25 & $12.31 \pm 0.36 \mathrm{a}$ & $13.18 \pm 0.13 \mathrm{a}$ & $12.058 \pm 0.06$ \\
\hline 125 & $11.39 \pm 0.20 \mathrm{abc}$ & $12.50 \pm 0.10 \mathrm{ab}$ & $12.478 \pm 0.05$ \\
\hline 625 & $10.96 \pm 0.19 \mathrm{bc}$ & $11.96 \pm 0.23 \mathrm{~b}$ & $11.862 \pm 0.09$ \\
\hline 3125 & $10.50 \pm 0.30 \mathrm{c}$ & $10.96 \pm 0.23 \mathrm{c}$ & $12.412 \pm 0.31$ \\
\hline $\mathrm{F}(\mathrm{df}=5)$ & $9.48^{* *}$ & $23.01^{* *}$ & 1.91 n.s. \\
\hline
\end{tabular}

According to the Tukey test $(\mathrm{p}=0.05)$ means having same letter within columns are not significantly different.

$* *=$ Significant at $1 \%$ level and n.s. $=$ Non Significant

Table 6:-The effect of phloroglucinol on Mean larval growth rate (mg/mg/day) when 64-72h old larvae of $B$. cucurbitae were fed on phloroglucinol incorporated in artificial diet.

\begin{tabular}{|c|c|c|c|}
\hline $\begin{array}{l}\text { Concentrations } \\
(\mathrm{ppm})\end{array}$ & $\begin{array}{c}\text { After 24h } \\
\text { (Mean } \pm \text { S.E.) }\end{array}$ & $\begin{array}{c}\text { After 48h } \\
\text { (Mean } \pm \text { S.E.) }\end{array}$ & $\begin{array}{c}\text { After 72h } \\
\text { (Mean } \pm \text { S.E.) }\end{array}$ \\
\hline 0 & $0.553 \pm 0.002 \mathrm{a}$ & $0.382 \pm 0.001 \mathrm{a}$ & $0.273 \pm 0.001 \mathrm{a}$ \\
\hline 5 & $0.550 \pm 0.004 \mathrm{ab}$ & $0.377 \pm 0.001 \mathrm{a}$ & $0.265 \pm 0.001 b$ \\
\hline 25 & $0.542 \pm 0.002 b c$ & $0.357 \pm 0.002 b$ & $0.256 \pm 0.002 c$ \\
\hline 125 & $0.538 \pm 0.003 \mathrm{~cd}$ & $0.358 \pm 0.002 b$ & $0.253 \pm 0.002 \mathrm{~cd}$ \\
\hline 625 & $0.535 \pm 0.003 \mathrm{~cd}$ & $0.354 \pm 0.002 b$ & $0.249 \pm 0.001 \mathrm{~d}$ \\
\hline 3125 & $0.528 \pm 0.003 d$ & $0.346 \pm 0.003 c$ & $0.240 \pm 0.002 \mathrm{e}$ \\
\hline $\mathrm{F}(\mathrm{df}=5)$ & $12.905 * *$ & $54.730 * *$ & $70.924 * *$ \\
\hline
\end{tabular}

According to the Tukey test $(\mathrm{p}=0.05)$ means having same letter within columns are not significantly different.

$* *=$ Significant at $1 \%$ level

Table 7:- The effect of phloroglucinol on Food assimilated (mg) when 64-72h old larvae of B. cucurbitae were fed on phloroglucinol incorporated in artificial diet.

\begin{tabular}{|c|c|c|c|}
\hline $\begin{array}{l}\text { Concentrations } \\
\text { (ppm) }\end{array}$ & $\begin{array}{c}\text { After 24h } \\
(\text { Mean } \pm \text { S.E. })\end{array}$ & $\begin{array}{c}\text { After } 48 \mathrm{~h} \\
\text { (Mean } \pm \text { S.E.) }\end{array}$ & $\begin{array}{l}\text { After 72h } \\
(\text { Mean } \pm \text { S.E. })\end{array}$ \\
\hline 0 & $12.607 \pm 0.036 \mathrm{a}$ & $19.487 \pm 0.077 \mathrm{a}$ & $21.604 \pm 0.104 a$ \\
\hline 5 & $12.510 \pm 0.023 \mathrm{ab}$ & $19.265 \pm 0.094 a$ & $20.008 \pm 0.056 b$ \\
\hline 25 & $12.390 \pm 0.055 b c$ & $18.579 \pm 0.043 b$ & $19.555 \pm 0.085 c$ \\
\hline 125 & $12.352 \pm 0.047 \mathrm{bcd}$ & $18.613 \pm 0.054 b$ & $19.346 \pm 0.078 \mathrm{~cd}$ \\
\hline 625 & $12.263 \pm 0.042 \mathrm{~cd}$ & $18.424 \pm 0.076 b c$ & $19.099 \pm 0.060 \mathrm{~d}$ \\
\hline 3125 & $12.185 \pm 0.040 \mathrm{~d}$ & $18.179 \pm 0.099 c$ & $18.647 \pm 0.069 \mathrm{e}$ \\
\hline $\mathrm{F}(\mathrm{df}=5)$ & $14.081 * *$ & $44.120 * *$ & $179.634 * *$ \\
\hline
\end{tabular}

According to the Tukey test $(\mathrm{p}=0.05)$ means having same letter within columns are not significantly different.

$* *=$ Significant at $1 \%$ level 


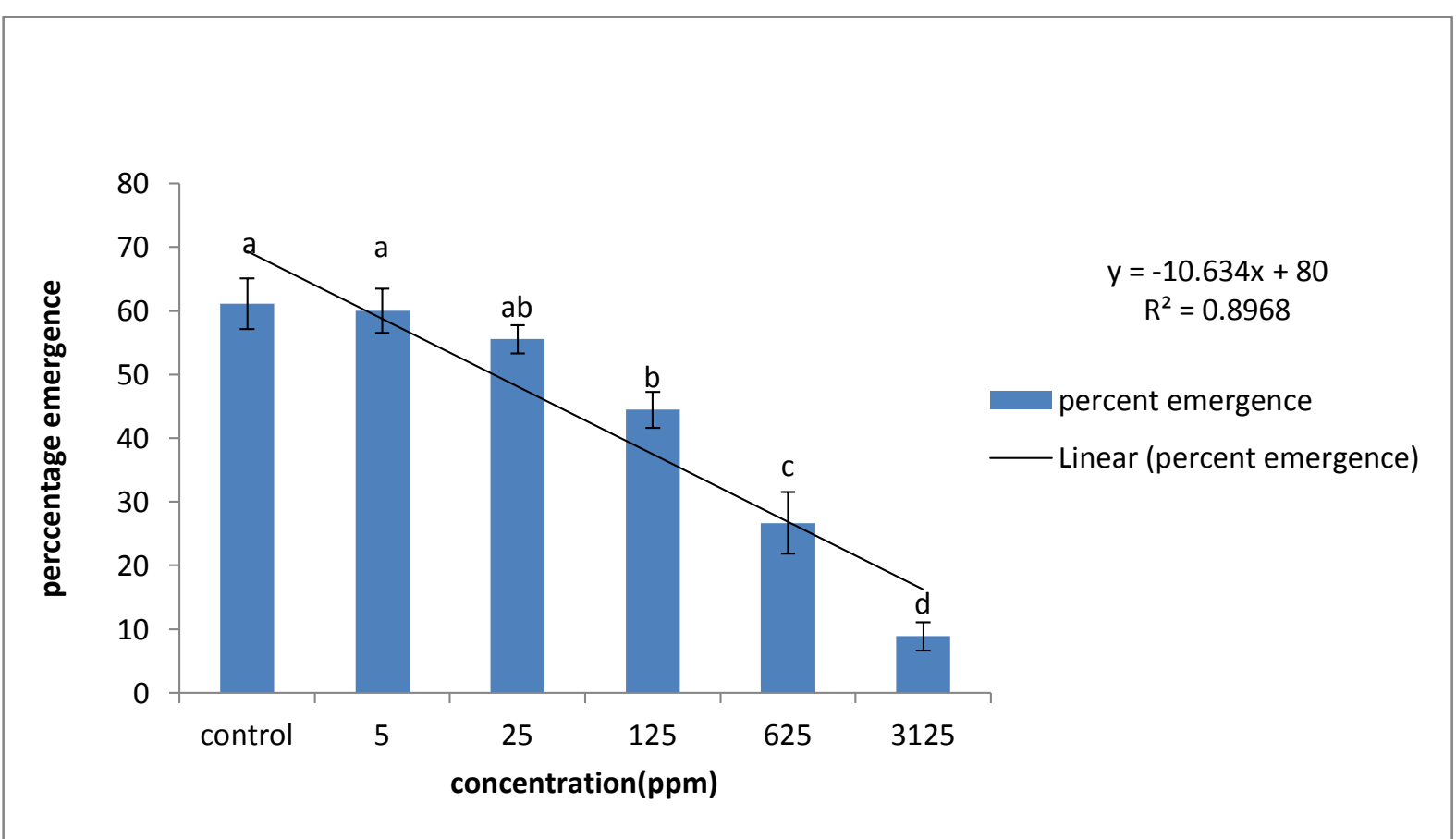

Figure1:-The effect of phloroglucinol on percent emergence of first instar larvae of B. cucurbitae. Bars represent mean value and standard error. Different letters indicate mean values that are significantly different (Tukey test, $p=$ $0.05)$.

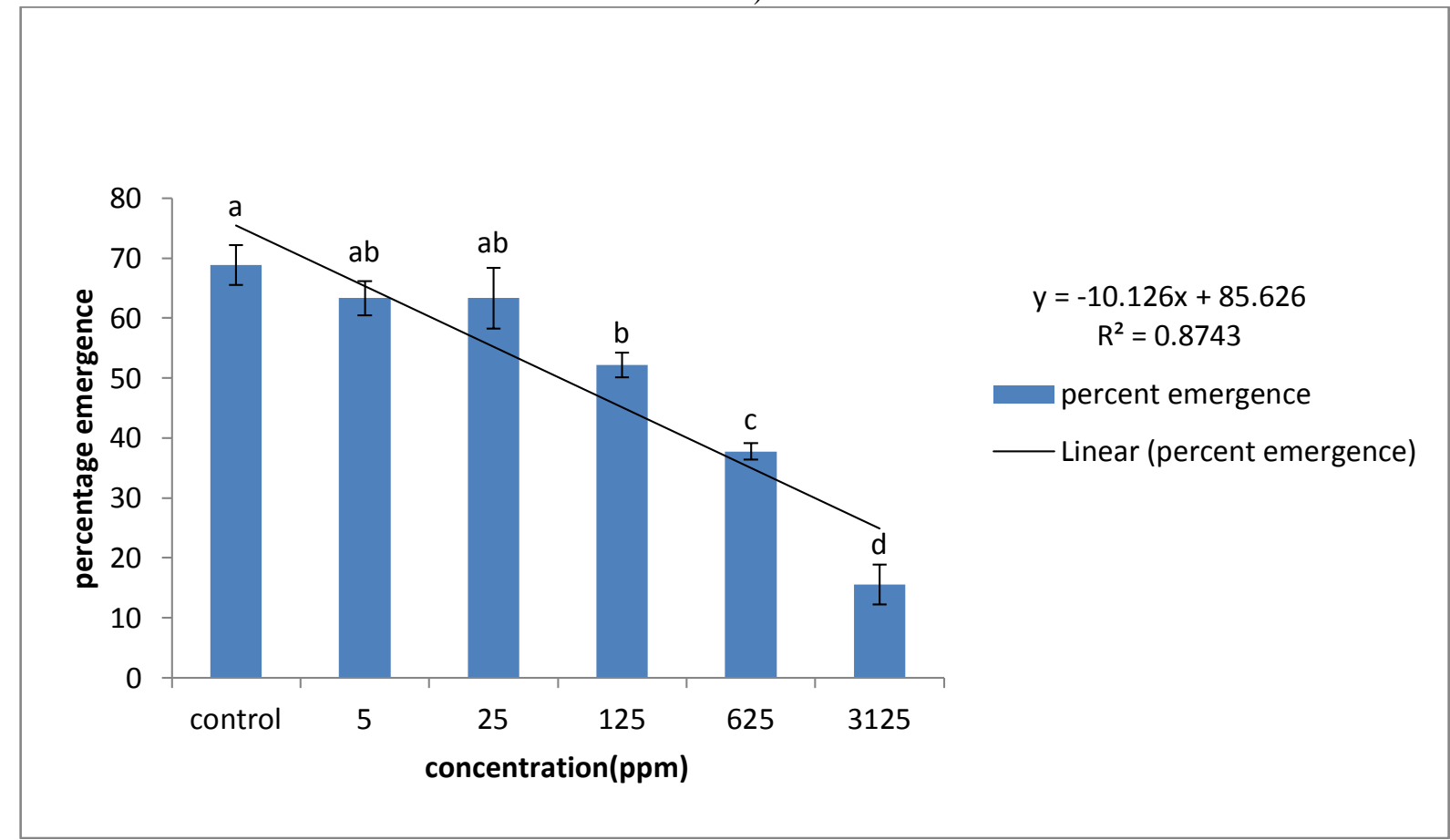

Figure2:- The effect of phloroglucinol on percent emergence of second instar larvae of B. cucurbitae. Bars represent mean value and standard error. Different letters indicate mean values that are significantly different (Tukey test, $\mathrm{p}=0.05$ ). 


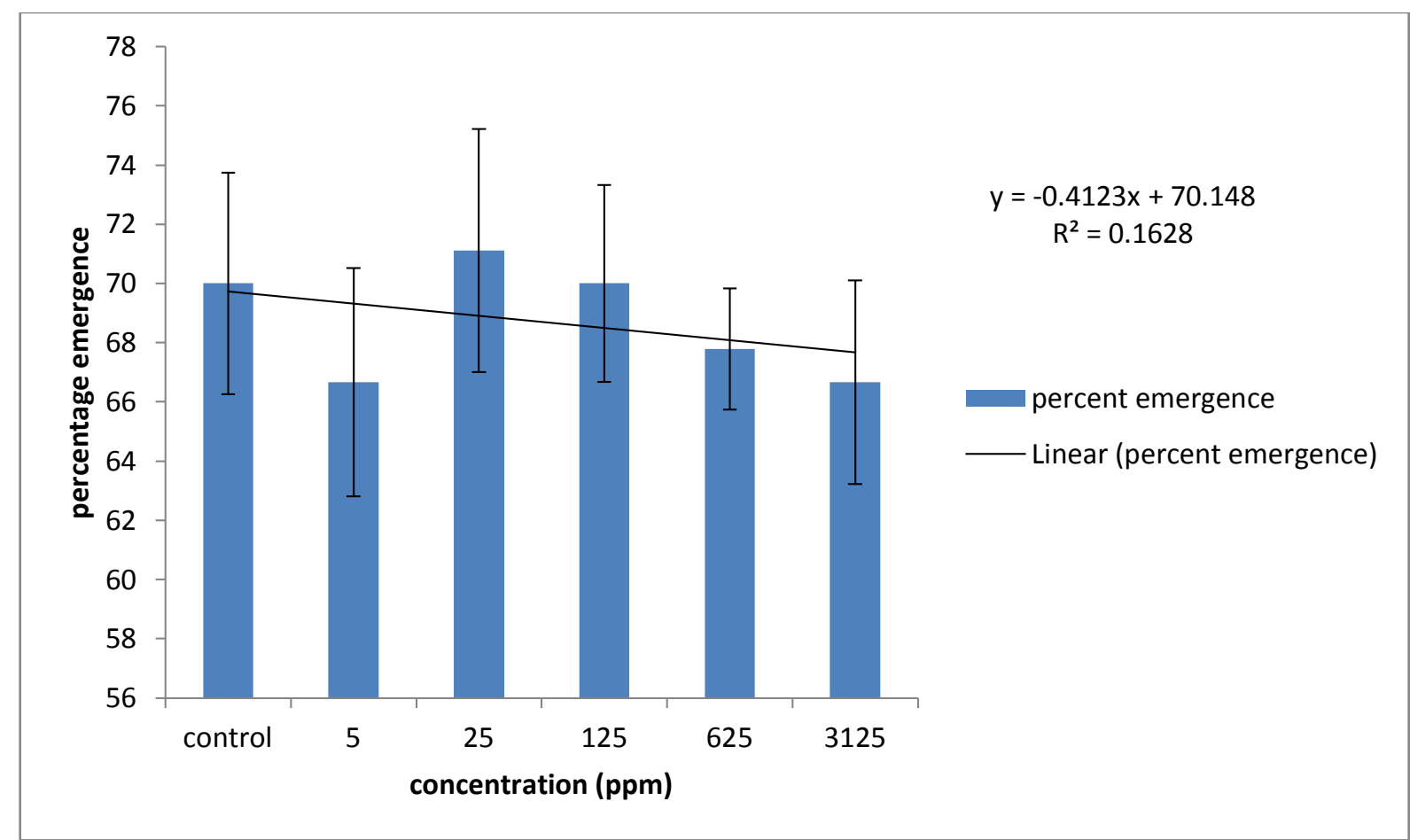

Figure3:-The effect of phloroglucinol on percent emergence of third instar larvae of $B$. cucurbitae. Bars represent mean value and standard error. Different letters indicate mean values that are significantly different $($ Tukey test, $\mathrm{p}=$ $0.05)$.

\section{Results and discussion:-}

Phloroglucinol showed an adverse effect on the development of first and second instar larvae of B. cucurbitae. The larval period and total developmental period was delayed significantly in the treatment of first and second instar larvae as compared to control. However no significant effect of phloroglucinol was observed on the development duration of third instar larvae. The delay in the larval and total developmental period was comparatively greater in first instar larvae than in the second instar larvae. In the treatment of first instar larvae the larval period was extended by 0.65 days and total developmental period was extended by 1.97 days at 3125 ppm concentration as compared to control (Tables 1 and 2). Delayed pupation of 2 to 5 days has also been perceived in Olive fruit fly, Dacus oleae Gmel. (Diptera: Tephritidae) when the larvae were fed on phloroglucinol incorporated diet (Manoukos, 1996). Phloroglucinol also increased the larval duration and survival of cotton bollworm, Heliothis armigera Hubner (Insecta: Noctuidae) (Ananthakrishnan et al., 1990). The delay in the larval and total development period of first and second instar larvae of $B$. cucurbitae indicates an antifeedant or toxic effect of the compound. A concentration dependent decrease in percent pupation and percent emergence was observed after incorporation of phloroglucinol in the diet given to the first and second instar larvae. In the first instar larvae, the percentage pupation was decreased by $29.85 \%$ while in the second instar larvae it was reduced by $20.26 \%$ at $3125 \mathrm{ppm}$ when compared to control (Table 3 ). The inhibitory effect of phloroglucinol was considerably greater on percentage emergence. The percentage of adults emerged reduced by $85.45 \%$ in the treatment of first instar larvae (Fig.1) and by $77.41 \%$ in the second instar larvae (Fig.2) as compared to control. The present findings are consistent with the results of Manoukas (1996) who also observed reduced percentage pupation and percentage emergence of B. oleae with increase in concentration of phloroglucinol. At higher concentrations of 0.4 and $0.8 \%$, the larvae fail to survive. Reese and Beck (1976) too perceived an inhibitory effect of phloroglucinol on percentage pupation of black cutworm, Agrotis ipsilon (Hufnagel) (Lepidoptera: Noctuidae). The present findings indicate toxicity of the compound induced after ingestion by the larvae of $B$. cucurbitae. No significant effect of phloroglucinol was observed on pupation and emergence in the treatment of third instar larvae of B. cucurbitae (Table 3 and Fig.3). Similar findings are reported by Aurade (2011) in Helicoverpa armigera (Hübner) (Noctuidae: Lepidoptera) where phloroglucinol has no significant effect on survival of third instar larvae. The tolerance of the third instar larvae of $B$. cucurbitae against phloroglucinol indicates that the larvae posses an ability to alleviate the toxic effects of phloroglucinol. Phloroglucinol also caused a significant decrease in pupal weight of melon fruit fly when first and second instar larvae were given treatment while the pupal weight of third instar was not affected by the incorporation of compound in the diet (Table 5). The 
larval weight of second instar decreased significantly with treatment when observations were made at three different time intervals (Table 4). The decrease in larval weight was concentration dependent. Mean relative growth rate was decreased with increasing time interval in second instar larvae (Table 6). Food assimilated by the second instar larvae was also affected in a negative manner in dose dependent manner. Inhibitory effects of phloroglucinol on feeding, growth and survival of black cutworm has been reported by Reese and Beck (1976). They observed that phloroglucinol inhibits growth of A. ipsilon (Hufnagel) (Lepidoptera: Noctuidae) by reducing the efficiency of conversion of assimilated food. Ananthakrishnan (1990) too has reported reduction in consumption index and mortality of the cotton bollworm, H. armigera after treatment with phloroglucinol. Pavela (2007) also has reported that phloroglucinol was among the two most effective phenols out of the nine phenols tested on third instar larvae of colorado beetle, Leptinotarsa decemlineata (Say) in decreasing feeding of larvae in dose dependent manner. Less weight of the larvae and pupae on treated diet compared to control diet suggests the inability of the larvae to feed or utilize the food for its growth. Sadek (2003) has suggested that the deterrent effect on feeding by insects may evolve due to chemical sensilla on mouth parts or retracted pulses coming from stomodael nervous system after ingestion. The present findings thus revealed a deterrent and toxic effect of ingestion of phloroglucinol on the early larval instars of B. cucurbitae.

\section{Conclusion:-}

The present findings indicate considerable potential of phloroglucinol to inhibit insect growth and can be used by plant breeders to enhance resistance in crops against insect pests.

\section{Acknowledgment:-}

The first author gratefully acknowledges UGC BSR and UGC SAP, New Delhi for providing grant for carrying out the present study.

\section{References:-}

1. Ananthakrishnan, T.N., Senrayan, R., Annadurai, R.S. and Murugesan, S. (1990). Antibiotic effects of resorcinol, gallic acid and phloroglucinol on Heliothis armigera Hubner (Insecta: Noctuidae). Proceedings: Ani. Sci. 99: 39-52.

2. Aurade, R.M., Akbar, S.M., Goud, H., Jayalakshmi, S.K., Sreeramulu, K., 2011. Inhibition of P-glycoprotein ATPase and its transport function of Helicoverpa armigera by morin, quercetin and phloroglucinol. Pestic. Biochem. Physiol., 101, 212-219.

3. Ghosh, A., Chowdhury, N. and Chandra, G. (2012): Plant extracts as potential mosquitolarvicides. Indian J. Med. Res., 135: 581-598.

4. Gupta, J.N. and Verma, A.N. (1978): Screening of different cucurbit crops for the attack of the melon fruit fly, Dacus cucurbitae Coquillett (Diptera: Tephritidae). Haryana J. Horti. Sci., 7(1): 78-82.

5. Jafri, W., Yakoob, J., Hussain, S., Jafri, N.and Islam, M. (2006): Phloroglucinol in irritable bowel syndrome. J Pak. Med Assoc., 56(1):5-8.

6. Kapoor, V. C. (1993). Economic fruit flies. In: Indian fruit flies (Insecta: Diptera:Tephritidae) (pp. 130-131). New Delhi, India: Oxford and DBH Publishing Co. Pvt. Ltd.

7. Kapoor, V.C. (2000): Indian fruit flies (Insecta: Diptera: Tephritidae), Oxford IBH Publishing Co. (P) Ltd., New Delhi.

8. Kang, K.A., Lee, K.H., Chae, S., Zhang, R., Jung, M.S., Ham, Y.M., Baik, J.S., Lee, N.H.and Hyun, J.W. (2006): Cytoprotective effect of phloroglucinol on oxidative stress induced cell damage via catalase activation. J. Cell. Biochem., 97:609-620.

9. Khan, Z.R. and Saxena, R.C. (1985): Behavioural and physiological responses of Sogatella furcifera (Homoptera: Delphacidae) to selected resistant and susceptible rice cultivars. J. Econ. Entomol., 78:1280-1286.

10. Kumar, N.K.K., Verghese, A., Shivakumara, B., Krishnamoorthy, P.N. and Ranganath, H.R. (2006) : Relative Incidence of Bactrocera cucurbitae (Coquillett) and Dacus ciliatus Loew on cucurbitaceous vegetables. Proc.of the $7^{\text {th }}$ Intern.Symposium on Fruit Flies of Economic Importance., pp. 249-253.

11. Mann, R.S. and Kaufman, P.E. (2012): Natural product pesticides: their development delivery and use against insect vectors. Mini Rev. Org. Chem., 9: 185-202.

12. Manoukas, A. G. (1996).The influence of four phenolics on the olive fruit fly. In McPheron B.A. and Steck G. J. (Eds.), Fruit fly pests, a world assessment of their biology and management (pp. 433-436). Delray Beach, FL, USA: St. Lucie Press. 
13. Martinez S.S. and Van Emden H.F. (2001): Growth disruption, abnormalities and mortality of Spodoptera littoralis (Boisduval) (Lepidoptera: Noctuidae) caused by azadirachtin. Neotrop. Entomol., 30:113-125.

14. Pavela, R. (2007): The feeding effect of polyphenolic compounds on the Colorado Potato Beetle (Leptinotarsa decemlineata Say). Pest Technol., 1, 81-84.

15. Pulido, R., Bravo, L., and Saura-Calixto, F. (2000): Antioxidant activity of dietary polyphenols as determined by a modified ferric reducing/antioxidant power assay. J. Agric. Food Chem., 48: 3396-3402.

16. Reese, J. C. And Beck, S. D. (1976): Effects of allelochemics on the black cutworm, Agrotis ipsilon; Effects of resorcinol, phloroglucinol, and gallic acid on larval growth, development, and utilization of food. Ann. Entomol. Soc. Am., 69:999- 1003

17. Ryu, J., Zhang, R., Hong, B., Yang, E., Kang, K.A., Choi, M., Kim, K.C., Noh,S., Kim,H.S., Lee, N., Hyun, J.W. and Kim, H. (2013): Phloroglucinol attenuates motor functional deficits in an animal model of Parkinson's disease by enhancing nrf2 activity. PLoS One 8, e71178, PLoSONE-D-13-00862 [pii].

18. Sadek, M.M. (2003). Antifeedant and toxic activity of Adhatoda vasica leaf extract against Spodoptera littoralis (Lep., Noctuidae). J. Appl.Ent., 127: 396-404.

19. Srivastava, B.G. (1975): A chemically defined diet for Dacus cucurbitae(Coq.) larvae under aseptic conditions. Entomol. News Lett., 5: 24.

20. Simmonds, M.S.J. ( 2001): Importance of flavonoids in insect-plant interactions: feeding and oviposition . Phytochem., 56: 245-252.

21. Singh, I. P.and Bharate, S. B. (2006): Phloroglucinol compounds of natural origin Nat. Prod. Rep., 23, 558-591.

22. Singh, I. P., Sidana, J., Bansal, P. and Foley, W. J. (2009): Phlorogluinol compounds of therapeutic interest:global patent and technology status. Exper Opin.Ther. Pat., 19(6), 847-866.

23. Singh, I.P., Sidana, J., Bharate, S.B. and Foley, W.J. (2010) : Phloroglucinol compounds of natural origin: Synthetic aspects, Nat. Prod. Rep., 393- 416.

24. Xu, A., Li, Y., Zhu L., Tian, T., Hao, J., Zhao, J. and Zhang, Q. (2013): Inhibition of endometrial fundocervical wave by phloroglucinol and the outcome of in vitro fertilization. Reprod. Biol.,13:88-91.

25. War, A.R., Paulraj, M.G., Ahmad, T., Buhroo, A.A., Hussain, B., Ignacimuthu, S. and Sharma, H.C. (2012): Mechanisms of plant defense against insect herbivores.Plant Signal. Behav., 7(10): 1306-1320.

26. White, I.M. and Elson-Harris, M. (1992) : Fruit flies of economic significance: Their identification and bionomics, pp:601. C.A.B. International: Wallingford (UK). 